\title{
Biomarkers in the Detection of Acute Renal Injury Associated with Cardiac Surgery
}

öz

Kardiyak cerrahi ile ilişkili akut böbrek hasarı da (KCi-ABH), yaklaşık \%30 oranında olup, postoperatif gelișen $A B H$ nedenleri arasında ikinci sırada yer almaktadır. $A B H$; artmıs morbidite, mortalite ve hastanede kalış süresi ile ilişkilidir. KCl-ABH insidansı, $A B H^{\prime}$ nin tanımlamasına bağlı olarak değişmekte, RIFLE, AKIN ve en son "Kidney Disease: Improving Global Outcomes (KDIGO)" kriterlerleri tanımlanmış ve günümüzde kullanılmaktadır.

$K C i-A B H$ etyopatogenezinde; eksojen ve endojen toksinler, metabolik anomaliler, iskemireperfüzyon hasarı, inflamasyon ve oksidatif stres gibi birçok faktör yer almaktadır. Birçok kez bu etyolojik nedenler tek başlarına değil, perioperatif dönemde hemodinamik instabilite, mikrosirkülatuar disfonksiyon, kardiyopulmoner baypas sırasında pompa akımı ve perfüzyon basıncı, hipotermi, hemodilusyon ve transfüzyon gibi faktörler aynı anda bulunup hasar oluşturma riskini katlanarak arttırmaktadırlar.

Ayrıca preoperatif dönemde hasta ile ilişkili; $K C i-A B H$ BH riskini arttıran birçok faktör belirtilmiştir. Cerrahi yöntem ve hasta ile ilişkili faktörlerin etkileşimi bu hastalarda, renal fonksiyonların azalmasına yol açmaktadır. Renal fonksiyonların ölçümünde kullanılan, idrar çıkışı ve serum kreatinin değerlerinin $A B H$ tespitindeki sınırlılıkları nedeniyle, daha duyarlı parametrelere ihtiyaç duyulmaktadır. Bu nedenle böbrek fonksiyonlarının bir belirteci olduğu düşünülen, sistatin C ilk olarak postoperatif $A B H^{\prime}$ nin erken tespiti için kullanılmış, ancak henüz net kanıtlar bulunamamıştır. Son dönemde; Interlökin-18 (IL-18), Nötrofil Gelatinaz ile ilişkili Lipokalin (NGAL), insulin-Benzeri Büyüme Faktörünü Bağlayıcı Protein (IGFBP7) ve Metallproteinaz 2'nin Doku Inhibitörü (TIMP-2) gibi daha duyarlı ve erken dönemde tespit edilebilen biyobelirteçlerin; hem $\mathrm{KCl}-\mathrm{ABH}$, hem de genel olarak $A B H^{\prime}$ nin tespiti için kullanılabileceğini belirten literatür verileri bulunmaktadır.

Anahtar kelimeler: akut böbrek hasarı, açık kalp cerrahisi, sistatin C, NGAL, IL-18

\section{ABSTRACT}

The incidence of cardiac surgery associated acute kidney injury (CSA-AKI) associated is about 30\% and it is the second most common cause of AKl; increased morbidity, mortality and hospital stay. The incidence of CSA-AKI varies depending on the definition of AKI, currently RIFLE, AKIN and the latest Kidney Disease: Improving Global Outcomes (KDIGO) criteria have been defined and being used today.

Many factors such as exogenous and endogenous toxins, metabolic anomalies, ischemiareperfusion injury, inflammation and oxidative stress are involved In the etiopathogenesis of. CSA-AKI; Many times these etiological factors, not alone but in combination of hemodynamic instability during perioperative period, microcirculatory dysfunction, pump flow during cardiopulmonary bypass and perfusion pressure, hypothermia, hemodilution and transfusion. increase the risk of acute renal injury.

Besides, many patient-related factors which also increase the risk of CSA-AKI have been found. The interaction between surgical method and patient-related factors leads to a decrease in renal function in these patients. More sensitive parameters are needed due to the limitations of urine output and serum creatinine levels used in the measurement of renal function in AKI Therefore, cystatin $C$, which is thought to be a marker of renal function, was initially used for early detection of postoperative AKI, but no clear evidence has yet been found. Recently; literature data indicating that more sensitive biomarkers that can be detected at an early stage such as Interleukin-18 (IL-18), Neutrophil Gelatinase-Associated Lipocalin (NGAL), Insulin-like Growth Factor-Binding Protein 7 (IGFBP7) and Tissue Inhibitor Metallproteinases 2 (TIMP-2); can be used in the detection of CSA-AKI and generally AKI can be used for detection.
Alındığı tarih: 08.05.2019

Kabul tarihi: 10.06 .2019

Yayın tarihi: 30.06 .2019

Emel Gündüz

Akdeniz Üniversitesi Tıp Fakültesi Anesteziyoloji ve Reanimasyon ABD Antalya - Türkiye dregunduz@hotmail.com ORCID: 0000-0002-0306-9770

T. Aydoğdu Titiz 0000-0003-0942-5067 Akdeniz Üniversitesi Tıp Fakültesi Anesteziyoloji ve Reanimasyon $A B D$ Antalya - Türkiye

Keywords: Akut kidney injury, open heart surgery, cystatin C, NGAL, IL-18 
Hastane yatışına bağlı kazanılmış akut böbrek hasarı $(A B H)$ \%2-18 oranında görülmekte ve kardiyak cerrahi ile ilişkili (KCi-ABH) ise yaklaşık \%30 olup, postoperatif gelişen $\mathrm{ABH}$ nedenleri arasında ikinci sırada yer almaktadır ${ }^{[1-6]}$. Kalp cerrahisi sonrası serum kreatinin düzeylerinde minimal bir artışın dahi olduğu hastalarda, 30 günlük mortalite 3 kat artmakta ve renal replasman tedavisi (RRT) gerektiren ciddi $\mathrm{ABH}$ olgularında, mortalitede \%63 oranında artış ortaya çıkmaktadır ${ }^{[7,8]}$.

$\mathrm{KCi}-\mathrm{ABH}$ sıklığı, $\mathrm{ABH}$ 'nin tanımlamasına bağlı olarak değişmekte olup, son yıllarda $A B H$ tanımlaması için konsensüs kriterleri yayınlanmıştır. Bunların ilki 2004 yılında "Acute Dialysis Quality Initiative (ADQI)" tarafından oluşturulan RIFLE (Risk, Injury, Failure, Loss of Function, End-Stage Kidney Disease) kriteridir. En son 2012 yılında "Kidney Disease: Improving Global Outcomes (KDIGO)" tarafından yeni bir tanımlama getirilmiştir ${ }^{[2,9]}$.

$\mathrm{KCI}-\mathrm{ABH}$ etyopatogenezinde; eksojen ve endojen toksinler, metabolik anomaliler, iskemi-reperfüzyon hasarı, nörohormonal aktivasyon, inflamasyon ve oksidatif stres gibi birçok faktör yer almaktadır ${ }^{[10]}$.

Cerrahi yöntem ve hasta ile ilişkili faktörlerin etkileşimi bu hastalarda, renal fonksiyonların azalmasına neden olmaktadır. Klasik olarak renal fonksiyonlar, serum kreatinin değerinin ölçümü ve idrar çıkış miktarı değerlendirilir. İdrar çıkışı ve serum kreatinin değerlerinin $A B H$ tespitindeki sınırılıkları nedeniyle, daha duyarlı parametrelere gereksinim duyulmaktadır. Son dönemde, böbrek hasarının erken belirlenmesini sağlayabileceği düşünülen bazı yeni belirteçlerin hem $\mathrm{KCI}-\mathrm{ABH}$ hem de genel olarak $A B H^{\prime}$ ıın belirlenmesi için kullanılabileceğini belirten literatür verileri bulunmakla birlikte, bu biyobelirteçlerin $\mathrm{ABH}$ belirlenmesindeki başarı oranları, örneğin Sistatin C'de olduğu gibi tartışmalıdır. Ancak, İnterlökin-18 (IL-18) ve Nötrofil Gelatinaz ile iliş̧kili Lipokalin'in (NGAL) daha duyarlı olduğu birçok çalışmada belirtilmiştir ${ }^{[11,12]}$.

\section{ABH Tanımı}

Akut böbrek hasarı $(A B H)$ renal fonksiyonlarda azalmaya bağlı olarak; serum kreatinin değerinde artma, glomerüler filtrasyon hızında ve idrar çıkışında azalma olarak tanımlanmaktadır. Bu nedenle akut böbrek yetmezliği tanısı bir klinik antite olan akut böbrek hasarına yerini bırakmıştır ${ }^{[13,14]}$.

RIFLE kriterleri, serum kreatin düzeyi ve idrar çıkış oranına göre düzenlenmiştir. Daha sonra AKIN grubu; $A B H$ tanısını süresini 7 günden 48 saate düşüren ve serum kreatin değerinin $26 \mathrm{mmol} / \mathrm{l}$ üzerinde olması gereken iki sınırlandırma ile modifiye etmiştir. Yapılan birçok çalışma sonucunda da her 2 sınıflandırmaya göre $K C i-A B H$ gelişen hastalarda, $A B H^{\prime} n ı n$ şiddeti ile mortalite arasında pozitif bir korelasyon olduğunu gösterilmiştir ${ }^{[15]}$. KDIGO konsensüsü ile ABH'nın şu an güncel olarak kabul edilen son sınıflandırılması geliştirilmiştir ${ }^{[14]}$ (Şekil 1).

Bu 3 kriter de $A B H ' n ı n$ tanımlanmasında idrar çıkışı ve serum kreatinin değerlerini baz almaktadır. Oligüri, uzamış açlığa, hipovolemiye, strese, ağrıya ve travmaya bağlı sekonder olabilir ${ }^{[16,17]}$.

Kreatinin yarılanma ömrü hastada renal hasar varlığında ortaya çıkan glomerüler filtrasyon hızı azalması nedeniyle 4 saatten 24-72 saate kadar uzamakta ve hasarın belirlenmesinde gecikmeye neden olmaktadir ${ }^{[18,19]}$.

\section{Kardiyak Cerrahi ile iliş̧ili ABH'nın Sıklığı}

KCi-ABH sıklığı, RIFLE ve AKIN kriterlerine göre \%9 ile \%39, KDIGO kriterlerine göre ise bu oran \%3.1 ile \%42 arasında değişmektedir ${ }^{[9]}$. Gözlemsel veriler kardiyak cerrahi ile ilişkili $\mathrm{ABH}$ gelişiminde hasta profilinin ve cerrahi tipinin önemli olduğunu göstermektedir. İzole CABG olan hastalarda \%2-5, kapak ve koroner cerrahisi birlikte olan hastalarda oran $\% 30$ olarak görülmektedir. Ayrıca ABH için risk faktörlerine sahip hastalarda ise bu oran $\% 50$ 'lere kadar yükselmektedir ${ }^{[20]}$. 


\begin{tabular}{|c|c|c|}
\hline RIFLE Kriterleri & S Kreatinin kriteri & İdrar çıkışı kriteri \\
\hline $\begin{array}{l}\text { Risk } \\
\text { Injury } \\
\text { Failure } \\
\text { Loss } \\
\text { ESKD }\end{array}$ & $\begin{array}{l}\text { Kreatinin artışı X } 1,5 \text { ya da GFH } \downarrow>\% 25 \\
\text { Kreatinin artışı X } 2 \text { ya da GFH } \downarrow>\% 50 \\
\text { Kreatinin artışı X } 3 \text { GFR } \downarrow>\% 75 \text { ya da } \\
\text { Kreatinin } \geq 4 \mathrm{mg} / \mathrm{dL} \text { ( } \geq 0,5 \mathrm{mg} / \mathrm{dL}^{\prime} \text { lik ani artış) } \\
\text { Persistan } \mathrm{ABH}=>4 \text { haftadır böbrek fonksiyon kaybı } \\
\text { Son dönem böbrek hastalığı (>3 ay) }\end{array}$ & $\begin{array}{l}<0,5 \mathrm{ml} / \mathrm{kg} / \mathrm{s} \times 6 \mathrm{~s} \\
<0,5 \mathrm{ml} / \mathrm{kg} / \mathrm{s} \times 12 \mathrm{~s} \\
\text { anuri } \times 12 \mathrm{~s}\end{array}$ \\
\hline AKIN Kriterleri & S Kreatinin kriteri & İdrar çıkışı kriteri \\
\hline $\begin{array}{l}\text { EVRE } 1 \\
\text { EVRE } 2 \\
\text { EVRE } 3\end{array}$ & $\begin{array}{l}\text { Kreatinin düzeyinde } \geq 0.3 \mathrm{mg} / \mathrm{dL}^{\prime} \text { lik artış ya da (bazalin } 1,5-2 \text { katı) } \\
\text { Kreatinin düzeyinde bazalin } 2-3 \mathrm{katı} \text { artış } \\
\text { Kreatinin düzeyinde bazalin }>3 \text { katı artış ya da serum kreatinin } \\
\text { düzeyinin } \geq 4 \mathrm{mg} / \mathrm{dl} \text { olması-en az } 0.5 \mathrm{mg} / \mathrm{dL}^{\prime} \text { lik akut artış olması }\end{array}$ & $\begin{array}{l}<0,5 \mathrm{ml} / \mathrm{kg} / \mathrm{s} \times 6 \mathrm{~s} \\
<0,5 \mathrm{ml} / \mathrm{kg} / \mathrm{s} \times 12 \mathrm{~s} \\
<0.3 \mathrm{ml} / \mathrm{kg} / \mathrm{s} \times 24 / \text { anürik } \times 12 \mathrm{~s}\end{array}$ \\
\hline KDIGO Kriterleri & S Kreatinin kriteri & İdrar çıkışı kriteri \\
\hline $\begin{array}{l}\text { EVRE } 1 \\
\text { EVRE } 2 \\
\text { EVRE } 3\end{array}$ & $\begin{array}{l}\text { Bazal değerden } 1.5-1.9 \text { kat ya da } \geq 0.3 \mathrm{mg} / \mathrm{dL} \text { artış } \\
\text { Bazal değerden } 2.0-2.9 \text { kat artış } \\
\text { Bazal değerden } 3 \text { kat artış ya da kreatinin }>4.0 \mathrm{mg} / \mathrm{dL} \\
\text { ya da RRT başlanması ya da }<18 \text { yaş hastalarda eGFR'de } \\
<35 \mathrm{ml} / \mathrm{dk} . / 1.73 \mathrm{~m}^{2} \text { azalma }\end{array}$ & $\begin{array}{l}<0,5 \mathrm{ml} / \mathrm{kg} / \text { saat } X 6-12 \mathrm{~s} \\
<0,5 \mathrm{ml} / \mathrm{kg} / \mathrm{saat} X \geq 12 \mathrm{~s} \\
\text { anüri } X \geq 12 \mathrm{~s}\end{array}$ \\
\hline
\end{tabular}

\section{ABH'nın Patofizyolojisinde Yer Alan Nedenler}

1. Hemodinamik instabilite: Birçok gözlemsel çalışma hemodinamik instabilite ile $\mathrm{ABH}$ gelişimi ve progresyonu arasında ilişki olduğunu göstermiştir [21,22]. Intraoperatif dönemde hipotansiyon ile $\mathrm{ABH}$ gelişimi arasında ilişki olduğu ve $O A B<55 \mathrm{mmHg}$ altında 30.000 olguluk bir çalışmada hipotansiyon 1-5 dk. gibi kısa süreli olsa dahi, postoperatif $A B H$ riskinin arttığı gösterilmiştir ${ }^{[21,23]}$.

Cerrahinin tipi, renal hipoperfüzyon için ayrıca risk oluşturmaktadır. Özellikle renal arter üzerinde yapılan ve aortaya kros-klemp konulan vasküler cerrahilerde bu risk artmaktadır ${ }^{[24]}$.

Son dönemde ise hastaların $O A B^{\prime}$ nın yeterli düzeylerde tutulmasına rağmen, bazı hastalarda $A B H$ gelişimine engel olunamadığını bildiren gözlemsel çalışmalarda kan basıncı defisiti olarak adlandırılan [ortalama perfüzyon basıncı $(O P B)=A O B-S V B$ (santral venöz basınç), diastolik perfüzyon basıncı (DPB)=DBSVB] parametrelerin perioperatif dönemde $A B H$ gelişiminin daha önemli bir göstergesi olduğu belirtilmektedir ${ }^{[25]}$.
2. Mikrosirkülatuar Disfonksiyon: $A B H$ gelişiminde renal kan akımı normal veya yüksek olmasına rağmen, intrarenal mikrosirkülatuar disfonksiyon nedeniyle $\mathrm{ABH}$ geliştiği gösterilmiştir [26].

Sepsis gibi inflamatuar durumlar, heterojen ve yavaşlamış bir kan akışı nedeniyle global hipoperfüzyon olmadan, böbrekte hipoperfüze olan ve iskemik alanların oluşmasına neden olur [27].

Hipoksik alanlar, intakt ve bozulmuş doku oksijenizasyonun olduğu bölgelerde görülebilir ve bu alanlar reaktif oksijen radikalleri oluşumu ile ilişkilidir ${ }^{[28]}$. Mikrosirkülasyondaki bu değişiklikler hemodinami düzelse bile devam edebilir ${ }^{[29]}$.

3. Endotel Disfonksiyonu: Yaygın sistemik inflamatuar mediatör salınımı sonrası endotelde glikokaliks hasarlanmasıyla mikrosirkülatuar disfonksiyon ortaya çıkar ve hücre bağlantıları bozulur ${ }^{[30,31]}$. Ayrıca endotelde artan adhezyon molekülü ekspresyonu, renal dokuya lökosit göçünü arttırır ve mikrosirkülatuar sistemde mikrotrombüs oluşumuna neden olur ${ }^{[32]}$.

4. Inflamasyon: Kardiyopulmoner baypas (KPB), 
sistemik inflamatuar yanıt sendromunun ortaya çıkmasına neden olur. Baypas devresinin yapay yüzeyi ile kan bileşenlerinin teması, iskemi-reperfüzyon hasarı, endotoksemi, operatif travma, nonpulsatil kan akışı ve önceden var olan sol ventrikül disfonksiyonu, immün aktivasyonun olası nedenleridir ${ }^{[33]}$.

Bu olaylar sitotoksik oksijen kaynaklı serbest radikallerin, proteazların, sitokinlerin ve kemokinlerin ortaya çıkmasına yol açar. IL-6, IL-8 ve TNF- $\alpha$ gibi inflamatuar mediatörlerin, KPB sırasında serum seviyelerinde artış görülür. KPB'nin sona ermesinden 2-4 saat sonra zirve değerlerine ulaşırlar ${ }^{[3,34]}$.

5. Tübüler Hücre Hasarı: Ekstrakorpereal dolaşımın kullanıldığı kardiyak cerrahilerde ortaya çıkan serbest hemoglobin, mikrodolaşım bozukluğuna ve tübüler hücre hasarına yol açar. Hücre membran bütünlüğünün bozulması, sıkı bağlantı kaybı, hücre şişmesi ve mitokondrial hasar sonucu ortaya çıkan serbest radikaller ise $\mathrm{ABH}$ gelişimini arttııır ${ }^{[35,36]}$.

6. Renal Venöz Konjesyon: Konjestif kalp yetmezliği, kritik hastalıklar veya renal ven kleplenmesi varlı̆̆ı renal obstrüksiyona neden olarak renal fonksiyonları olumsuz aynı mekanizma ile AKI gelişme riskini arttırdığı bilinmektedir ${ }^{[37-39]}$.

\section{Kardiyak Cerrahi ile iliş̧kili ABH}

KCi-ABH, patofizyolojisi karmaşık ve büyük olasılıkla birden fazla farkı faktörü içeren bir süreçtir. Olası hasar nedenleri; hipoperfüzyon, iskemi reperfüzyon hasarı, nörohormonal aktivasyon, inflamasyon, oksidatif stress, nefrotoksinler ve mekanik faktörlerdir. Tablo 1'de bu hasarlanmaya katkıda bulunan preoperatif, intraoperatif ve postoperatif nedenler sıralanmıştır.

\section{Preoperatif Period}

Preoperatif $A B H$ riskleri genellikle hasta kaynaklı olmakla birlikte, kardiyovasküler hastalık tedavisi sonucu olarak da ortaya çıkabilir. Diyabet, düşük kardiyak output, düşük renal rezervler ve ateroskleroz bu hastalarda sık görülmekte $\mathrm{ABH}$ riskini arttırmaktadir ${ }^{[40]}$.

Konjestif kalp yetmezliğinde renal kan akımının azalması; renin-anjiotensin-aldosteron (RAA) ve sempatik sinir sistemini aktive ederek, vazokonstriksiyon ve azalmış nitrik oksit (NO) sentezine yol açarak renal kan akımında azalmaya yol açar ${ }^{[41]}$.

Cerrahi öncesi son opak maruziyet süresinin renal fonksiyonlar üzerine etkisi olduğu bilinmekte ve ameliyatta 24 saat önce koroner anjiografi yapılan

Tablo 1. ABH gelişimine katkıdan bulunan nedenler.

\begin{tabular}{|c|c|c|}
\hline Preoperatif & İntraoperatif & Postoperatif \\
\hline $\begin{array}{l}\text { Komorbidite varlığı } \\
\text { İleri yaş } \\
\text { Kadın cinsiyet } \\
\text { Hipertansiyon } \\
\text { Hiperlipidemi } \\
\text { Sigara } \\
\text { Periferik vasküler hastalık } \\
\text { Renal reservin azlığı } \\
\text { Renovasküler hastalık } \\
\text { Düşük sol ventrikül fonksiyonu } \\
\text { Embolizm } \\
\text { Nefrotoksinler } \\
\text { Kontrast madde } \\
\text { IABP kullanımı } \\
\text { Yüksek WBC düzeyleri } \\
\text { Diyabet } \\
\text { Anemi }\end{array}$ & $\begin{array}{c}\text { Cerrahinin tipi } \\
\text { Hipoperfüzyon } \\
\text { Hemodilüsyon } \\
\text { Hemoliz } \\
\text { Transfüzyon } \\
\text { İnflamasyon } \\
\text { Emboli } \\
\text { Venöz konjesyon } \\
\text { Aort kros klemp süresi }\end{array}$ & $\begin{array}{c}\text { Düşük kardiyak output } \\
\text { Inflamasyon } \\
\text { Transfüzyon } \\
\text { Vazopressör kullanımı } \\
\text { Inotrop kullanımı } \\
\text { Diüretik kullanımı } \\
\text { Anemi }\end{array}$ \\
\hline
\end{tabular}


hastalarda, cerrahi sonrası böbrek hasarı riskinin 5 kat arttığı bildirilmişstir ${ }^{[42,43]}$.

\section{Kardiyopulmoner baypas sırasında pompa akımı} Kardiyak cerrahide kullanılan KPB’a bağlı akut böbrek hasarı arasındaki ilişki; yeni teknikler ve kullanılan materyallerin iyileştirilmesine rağmen, azalmakla birlikte devam etmektedir ${ }^{[44]}$.

KPB sırasında optimal organ perfüzyonun devam ettirilmesi için pompa akımı 2,2-2,4 l/dk./ $/ \mathrm{m}^{2}$ seviyesinde tutulur. Abramov ve ark.'nın ${ }^{[45]} 1820$ hastayı içeren çalışmasında, pulsatil akım kullanılan pompa sistemlerinin, nonpulsatiflere göre böbrek fonksiyonunu iyileştirdiğine dair bir veri saptayamamışlardır. Bu nedenle günümüzde çoğu merkez tarafından nonpulsatif pompa sistemleri kullanılmaktadır.

\section{Kardiyovasküler baypas sırasında perfüzyon basıncı}

Akış hızı ve perfüzyon basıncı, baypas sırasında bölgesel kan akışını belirler. Böbreklere yeterli oksijen sunumu için pompa sırasında, normal kardiyak output'la birlikte, $50-70 \mathrm{mmHg}$ arası perfüzyon basıncında tutularak renal koruma sağlanmasına rağmen, bu hedeflerin preoperatif böbrek hasarı olan, otoregülasyonu bozuk olgularda veya Akut tubüler nekroz gelişmiş böbreklerde koruyucu olup olmadığı bilinmemektedir ${ }^{[46]}$.

Kanji ve ark. ${ }^{[47]}$, intraoperatif $O A B$ değerinin yüksekli riskli hasta grubunda, preoperatif $O A B$ ölçümüne kıyasla $26 \mathrm{mmHg}$ veya daha fazla düştüğünde perfüzyon basıncının $\mathrm{ABH}$ gelişimi ile yakından ilişkili olduğunu göstermişlerdir.

\section{Kardiyopulmoner baypas sırasında hipotermi}

Kardiyopulmoner bypass ile yapılan cerrahilerde organ koruması için hafif ya da orta derecede sistemik hipotermi $\left(32-36^{\circ} \mathrm{C}\right)$ kullanılır. Düşük kan kaybının ve dolaşım durdurulmasının planlandığı cerrahilerde ise bu hipotermi daha derin $\left(15-25^{\circ} \mathrm{C}\right)$ uygulanır.

KPB’a bağlı böbrek hasarı, hipotermik ile normotermik KPB karşılaştırıldığında sonuçlar çelişkili bulun- maktadır. Bunun bir nedeni de sıcaklık monitörizasyonunun farklı yerlerden yapılmış olması olabilir. Boodhwani ve ark.'nın ${ }^{[48]}$ randomize kontrollü bir çalışmasında, KPB uygulanan 450 hasta; cerrahi sırasında $32^{\circ} \mathrm{C}^{\prime}$ ye soğutulmuş ve daha sonra hastalar KPB' den ayrılırken 2 grupta baypas cihazından ayrılırken sırasıyla $34^{\circ} \mathrm{C}$ ve $37^{\circ} \mathrm{C}^{\prime}$ ye yeniden ısıtılmış olup, $37^{\circ} \mathrm{C}^{\prime}$ ye kadar ısıtılanlarda, $\mathrm{ABH}$ sıklığının daha yüksek olduğu görülmüştür.

\section{İflamatuvar sistem}

Kardiyopulmoner baypas ile ilişkili ortaya çıkan bu inflamatuar yanıtın ana nedenleri, baypas devresinin yapay yüzeyi ile doğrudan temas eden kan, iskemireperfüzyon hasarı ve endotokseminin varlığıdır. Diğer olası nedenler ise operatif travma, nonpulsatil kan akımı ve var olan sol ventrikül disfonksiyonudur [47]. Dolaşımda artan miktarda inflamatuar mediatör varlığı ise endotel disfonksiyonuna yol açarak $A B H^{\prime}$ nın ortaya çıkmasını tetikleyebilir ${ }^{[49-51]}$.

KPB ve kros klempin güvenli süreleri bilinmemekle beraber, bu etkenlerin süresi uzadıkça $A B H$ sıklığı artmaktadır ${ }^{[50]}$. SIRS ve KPB sırasında ortaya çıkan hemoliz, ABH riskini arttırmaktadır.

\section{Hemodilüsyon}

KPB'a başlanması ile ortaya çıkan hemodilüsyon; hipotermi ve hipoperfüzyon gelişen bu süreçte vücutta bölgesel kan akımını iyileştirir. Postoperatif $A B H$ riskinin, hemotokritin \%21-24 seviyesinin altındaki hastalarda arttığı bildirilmiştir ${ }^{[52]}$.

Perel , intraoperatif süreçte cerrahi türünden bağımsIz, iatrojenik olarak oluşan hemodilüsyon sonrası ortaya çıkan rölatif hemoglobin düşüşünün daha fazla kan transfüzyonuna ve sistemik oksijen sunumunda $\left(\mathrm{DO}_{2}\right)$ paradoksik bir düşüşe neden olabileceğine dikkat çekmiştir. Bu etki, pompada kullanılan prime solüsyon miktarı nedeniyle önem kazanmaktadır ${ }^{[53]}$.

Preoperatif böbrek hastalığı veya anemisi olan duyarIı hastalarda preoperatif eritrosit transfüzyonu $\mathrm{ABH}$ için bir risk faktörü olarak düşünülmektedir ${ }^{[54]}$. 
Özellikle 14 günden fazla depolanan eritrositlerin transfüzyonu; inflamasyon, renal hipoksi ve oksidatif stres gibi zararlı etkiler ortaya çıkabilir ${ }^{[55]}$.

\section{Postoperatif Period}

Hastanın postoperatif dönemdeki hemodinamik durumu, böbrek fonksiyonlarını en çok etkileyen etmendir. Kardiyopulmoner baypas ayrıldıktan sonra bazı hastalar inotrop, vazopressör, intraaortik balon pompası (IABP) veya sol ventrikül destek sistemleri (LVAD) gibi hemodinamik desteklere gereksinim duyarlar. Bu tedavi rejimleri böbrek perfüzyonunu etkileyerek, inflamatuar yanıtı arttırabilir ve dolayısıyla böbrek fonksiyonlarını bozabilir ${ }^{[56]}$. Kalp cerrahisi sonrası gelişen kardiyak tamponad, dolaşım fonksiyonlarını bozabilir. Tamponad sonrası hastanın reeksplorasyonu ve yüksek miktarda kan transfüzyonunun da $A B H$ sıklığını arttırdığı bilinmektedir [57]. Postoperatif uygulanan nefrotoksik ilaçlar da böbrek hasarı için risk oluşturur ${ }^{[58]}$.

\section{Böbrek Hasar Markerları}

Kalp cerrahisi sonrası, serum kreatin değişiklikleri ancak tübüler hasardan 48 saat sonra ortaya çıkar ki, bu durum $A B H^{\prime}$ ın azaltılması için yapılacak işlemlerin gecikmesine yol açar.

$\mathrm{Bu}$ nedenle kardiyak cerrahi sonrası daha erken hasar belirlenmesi için yeni markerlar üzerinde çalışılmıştır. Sistatin C böbrek fonksiyonu için kreatininden daha hassas bir belirteç olup, neredeyse tamamı proksimal renal tübüler hücrelerden geri emilir ve katabolize edilir. İdrarda normalde bulunmayan sistatin C'nin, idrarda saptandığında tübüler epitel hasarını gösteren duyarlı bir biyobelirteç olduğu belirtilmiştir ${ }^{[59,60]}$.

$\mathrm{Bu}$ biyobelirteçler, özelliklerine göre farklı doğa, büyüklük ve hasar bölgesini yansıtır. Bunlardan NGAL, diğer adıyla lipocalin-2, böbrek proksimal tübül hücrelerinde iskemik veya toksik hasar sonrası up-regüle edilir ${ }^{[61]}$. ABH belirlenmesinde NGAL'in eşik değeri ile ilgili çalışma verileri değişken olup, Fodorve ark.'na ${ }^{[62]}$ göre eşik değer 257 ng/dL, 244 çalışmanın derlen- diği başka bir meta analizde ise NGAL'in cutoff değerleri $50 \mathrm{ng} / \mathrm{dL}$ ile $550 \mathrm{ng} / \mathrm{dl}$ arasında değiştiği belirtilerek, NGAL'in erişkinlerde 100-270 ng/dL'nin (median değer: $170 \mathrm{ng} / \mathrm{dL}$ ) üzerinde olması $A B H$ tanısı için eşik değer olarak tanımlanmıştır ${ }^{[63]}$.

IL-18, çeşitli antijen sunan hücreler tarafından salgılanan bir proinflamatuar molekül olup, kronik böbrek hastalığı ve $A B H^{\prime}$ da erken dönemde plazma ve idrar seviyelerinin arttığı bildirilmektedir ${ }^{[61]}$.

Son zamanlarda, erişkinlerde yapılan çok merkezli iki kohort çalışmasında, NGAL, IL-18, KIM-1 ve L-FABP'nin işlevi kalp cerrahisinde değerlendirilmiştir [62]. Çalışılan tüm biyobelirteçler, KIM-1 dışında, ameliyattan sonraki 6 saat içinde pik yaptıkları, KiM-1'in ise, ameliyattan 2 gün sonra pik yaptığı ve birkaç gün boyunca yüksek kaldığı görülmüştür ${ }^{[64]}$.

ABH'na yol açan tübüler hasarı postoperatif yaklaşık 2-3 saat gibi erken dönemde saptamada idrar IL-18 ve plazma NGAL, düzeylerinin yazarlar tarafından olumlu birer biyomarker olduğunu ve $A B H^{\prime}$ nın artmasını tahmin etmede yardımcı olduklarını bildirmişlerdir ${ }^{[61,62]}$.

İki yeni renal marker olan İnsulin-like Growth FactorBinding Protein 7 (IGFBP7) ve Tissue Inhibitor of Metallproteinases 2 (TIMP-2)'nin idrarda kardiyopulmoner baypas başladıktan 1 saat sonra çok erken dönemde belirlenebileceği böylece $A B H^{\prime}$ ında prediktif olduğu bildirilmiştir ${ }^{[65]}$.

Yapılan son çalışmalarda da serum IL-18 ve NGAL düzeylerinin ölçümünün $\mathrm{ABH}$ tespitinde diğer markerlara göre daha duyarlı olduğu gösterilmiştir ${ }^{[61,66]}$.

Parikh ve ark.'nın ${ }^{[67]}$ yaptığı bir çalışmada, idrar IL-18 seviyelerinin $A B H^{\prime} n ı$ belirlemedeki sensitivite ve spesifite oranlarının $\% 90$ 'ın üzerinde olduğu belirtmişlerdir.

Lin ve ark. ${ }^{[68]}$ serum IL-18 düzeylerinin, hastane mortalite tahmini için ve renal replasman tedavisi gerek- 
tiren böbrek hasarının ayırıcı tanısında diğer yöntemlere göre daha üstün olduğunu göstermişlerdir. Blankenberg ve ark. ${ }^{[69]}$ tarafından yapılan çalışmada ise, serum IL-18 konsantrasyonun, koroner olayların gelişme riskinin bir belirteci olabileceği belirtilmiştir.

Kardiyak cerrahiye bağlı gelişen $A B H^{\prime} n$ ı önlemede, gelecekte risk tayini belirlenmesinde erken biyomarkerların bulunması, gerçek zamanlı GFR ölçümü yapan, böbrek perfüzyonu ve intrakapsüler membran basıncı gibi monitörlerin kullanılmaya başlamasıyla hastanın hemodinamisinin takibi, belki de stemcell hücrelerinin de yeri olabileceği düşünülmektedir $[70,71]$.

Akut böbrek hasarına yol açan nedenlerin belirlenmesi ve erken dönem böbrek hasarı için kullanılan belirteçlerin doğruluğunu test etmek için daha büyük olgu serileriyle yapılacak çalışmalara gereksinim olduğu açıktır.

\section{KAYNAKLAR}

1. Hobson C, Singhania G. Acute Kidney Injury in the Surgical Patient. Crit Care Clin 2015;31(4):705-23. https://doi.org/10.1016/j.ccc.2015.06.007

2. Vandenberghea V, De Loor J. Diagnosis of cardiac surgery-associated acute kidney injury from functional to damage biomarkers. Curr Opin Anesthesiol 2017;30:66-75.

3. Romagnoli S. Therapy of acute kidney injury in the perioperative setting. Current Opinion in Anaesthesiology 2017;30(1):92-9. https://doi.org/10.1097/ACO.0000000000000424

4. Zarbock A. Cardiac surgery-associated acute kidney injury: much improved, but still long ways to go. Curr Opin Anesthesiol. 2017;30:58-9. https://doi.org/10.1097/ACO.0000000000000429

5. KDIGO AKI Work Group. KDIGO clinical practice guideline for acute kidney injury. Kidney Int Suppl 2012;2:1138.

6. Waikar SS, Liu KD, Chertow GM. Diagnosis, epidemiology and outcomes of acute kidney injury. Clin J Am Soc Nephrol. 2008;3:844-61.

https://doi.org/10.2215/CJN.05191107

7. Karkouti K, Wijeysundera DN. Acute kidney injury after cardiac surgery: focus on modifiable risk factors. Circulation 2009;119:495-502.
https://doi.org/10.1161/CIRCULATIONAHA.108.786913

8. Lassnigg A, Schmidlin D. Minimal changes of serum creatinine predict prognosis in patients after cardiothoracic surgery: a prospective cohort study. J Am Soc Nephrol. 2004;15:1597-605. https://doi.org/10.1097/01.ASN.0000130340.93930.DD

9. Bellomo R, Ronco C, Kellum JA, Mehta RL, Palevsky P. Acute renal failure - definition, outcome measures, animal models, fluid therapy and information technology needs: the Second International Consensus Conference of the Acute Dialysis Quality Initiative (ADQI) Group. Crit Care 2004;8:204-12. https://doi.org/10.1186/cc2872

10. Bellomo R, Auriemma S. The pathophysiology of cardiac surgery-associated acute kidney injury (CSA-AKI). Int J Artif Organs 2008;31:166-78. https://doi.org/10.1177/039139880803100210

11. Bagshaw SM, Bellomo R. Cystatin C in acute kidney injury. Curr Opin Crit Care 2010;16:533-9. https://doi.org/10.1097/MCC.0b013e32833e8412

12. Prowle JR, Calzavacca P. Combination of biomarkers for diagnosis of acute kidney injury after cardiopulmonary bypass. Ren Fail 2015;37(3):408-16. https://doi.org/10.3109/0886022X.2014.1001303

13. Ostermann M, Joannidis M. Acute kidney injury 2016: diagnosis and diagnostic workup. Critical Care 2016;20:299. https://doi.org/10.1186/s13054-016-1478-z

14. Kellum JA, Lameire N. Diagnosis, evaluation, and management of acute kidney injury: a KDIGO summary (Part 1). Crit Care 2013;17:204. https://doi.org/10.1186/cc11454

15. Haase M, Bellomo R. Comparison of the RIFLE and Acute Kidney Injury Network classifications for cardiac surgery-associated acute kidney injury: a prospective cohort study. J Thorac Cardiovasc Surg. 2009;138:1370-6. https://doi.org/10.1016/j.jtcvs.2009.07.007

16. Guay J, Lortie L. Activation of the renin-angiotensin system contributes significantly to the pathophysiology of oliguria in patients undergoing posterior spinal fusion. Eur J Anaesthesiol. 2004;21(10):812-8. https://doi.org/10.1017/S0265021504000109

17. Lehner GF, Forni LG, Joannidis M. Oliguria and biomarkers of acute kidney injury: star struck lovers or strangers in the night? Nephron 2016;133(4):183-90. https://doi.org/10.1159/000447979

18. Doi K, Yuen PS, Eisner C, Hu X, Leelahavanichkul A, Schnermann J, Star RA. Reduced production of creatinine limits its use as marker of kidney injury in sepsis. J Am Soc Nephrol. 2009;20(6):1217-21. https://doi.org/10.1681/ASN.2008060617

19. Macedo E, Bouchard J, Soroko SH, et al. Fluid accumu- 
lation, recognition and staging of acute kidney injury in critically-ill patients. Crit Care 2010;14:82.

https://doi.org/10.1186/cc9004

20. Reents W, Hilker M. Acute kidney injury after on-pump or off-pump coronary artery bypass grafting in elderly patients. Ann Thorac Surg. 2014;98:9-14. https://doi.org/10.1016/j.athoracsur.2014.01.088

21. Post EH, Kellum JA, Bellomo R, et al. Renal perfusion in sepsis: from macro- to microcirculation. Kidney Int 2017;91:45-60. https://doi.org/10.1016/j.kint.2016.07.032

22. Raimundo $M$, Crichton $S$, Syed $Y$, et al. Low systemic oxygen delivery and blood pressure and risk of progression of early acute kidney injury. Clin J Am Soc Nephrol. 2015;10(8):1340-9. https://doi.org/10.2215/CJN.02780314

23. Salmasi V, Maheshwari K, Yang D, et al. Relationship between intraoperative hypotension, defined by either reduction from baseline or absolute thresholds, and acute kidney and myocardial injury after noncardiac surgery: a retrospective cohort analysis. Anesthesiology 2017;126(1):47-65. https://doi.org/10.1097/ALN.0000000000001432

24. Sansone F, Morgante A. Prognostic implications of acute renal failure after surgery for type $A$ acute aortic dissection AORTA 2015;3(3):91-7. https://doi.org/10.12945/j.aorta.2015.14.022

25. Saito S, Uchino S, Takinami M, Uezono S, Bellomo R. Postoperative blood pressure deficit and acute kidney injury progression in vasopressor dependent cardiovascular surgery patients. Crit Care 2016;20(1):74. https://doi.org/10.1186/s13054-016-1253-1

26. Prowle J, Bagshaw SM, Bellomo R. Renal blood flow, fractional excretion of sodium and acute kidney injury: time for a new paradigm? Curr Opin Crit Care 2012;18(6):585-92. https://doi.org/10.1097/MCC.0b013e328358d480

27. Matejovic M, Ince C, Chawla LS, et al. Renal Hemodynamics in AKI: In Search of New Treatment Targets. J Am Soc Nephrol 2016;27:49-58. https://doi.org/10.1681/ASN.2015030234

28. Wang Z, Holthoff JH, Seely KA, et al. Development of oxidative stress in the peritubular capillary microenvironment mediates sepsis-induced renal microcirculatory failure and acute kidney injury. Am J Pathol. 2012;180:505-16. https://doi.org/10.1016/j.ajpath.2011.10.011

29. Legrand M, Mik EG, Johannes T, et al. Renal hypoxia and dysoxia after reperfusion of the ischemic kidney. Mol Med. 2008;14:502-16. https://doi.org/10.2119/2008-00006.Legrand

30. Zafrani L, Payen D, Azoulay E, et al. The microcirculation of the septic kidney. Semin Nephrol. 2015;35:75-
84.

https://doi.org/10.1016/j.semnephrol.2015.01.008

31. Verma S, Molitoris BA. Renal endothelial injury and microvascular dysfunction in acute kidney injury. Semin Nephrol. 2015;35(1):96-107. https://doi.org/10.1016/j.semnephrol.2015.01.010

32. Molitoris B. Therapeutic translation in acute kidney injury: the epithelial/endothelial axis. J Clin Invest 2014;124:2355-63. https://doi.org/10.1172/JCl72269

33. Kinsey GR, Sharma R, Huang $L$, et al. Regulatory T cells suppress innate immunity in kidney ischemiareperfusion injury. J Am Soc Nephrol. 2009;20(8):174453. https://doi.org/10.1681/ASN.2008111160

34. Zhang WR, Garg AX, Coca SG, et al. Plasma IL-6 and IL-10 concentrations predict AKI and long-term mortality in adults after cardiac surgery. J Am Soc Nephrol 2015;26(12):3123-32. https://doi.org/10.1681/ASN.2014080764

35. Qian Q, Nath KA, Wu Y, et al. Hemolysis and acute kidney failure. Am J Kidney Dis. 2010;56(4):780-4. https://doi.org/10.1053/j.ajkd.2010.03.025

36. O'Neal JB, Shaw AD, Billings FT. 4th Acute kidney injury following cardiac surgery: current understanding and future directions. Crit Care 2016;20(1):187. https://doi.org/10.1186/s13054-016-1352-z

37. Agarwal A, Dong Z, Harris R, et al. Cellular and molecular mechanisms of AKI. J Am Soc Nephrol. 2016;27:128899. https://doi.org/10.1681/ASN.2015070740

38. Firth J, Raine A, Ledingham J. Raised venous pressure: a direct cause of renal sodium retention in oedema? Lancet 1988;1(8593):1033-5. https://doi.org/10.1016/S0140-6736(88)91851-X

39. Maxwell M, Breed E, Schwartz I. Renal venous pressure in chronic congestive heart failure. J Clin Invest. 1950;29(3):342-8. https://doi.org/10.1172/JCl102263

40. Mullens W, Abrahams Z, Francis GS, et al. Importance of venous congestion for worsening of renal function in advanced decompensated heart failure. J Am College Cardiol. 2009;53(7):589-96. https://doi.org/10.1016/j.jacc.2008.05.068

41. Ross EA. Congestive renal failure: The pathophysiology and treatment of renal cenous hypertension. Journal of Cardiac Failure 2012;18(12):930-8. https://doi.org/10.1016/j.cardfail.2012.10.010

42. Kim DH, Shim JK, Hong SW, et al. Predictive value of $\mathrm{C}$-reactive protein for major postoperative complications following off-pump coronary artery bypass surgery: prospective and observational trial. Circ J 2009; 73:872-7. 
https://doi.org/10.1253/circj.CJ-08-1010

43. Ranucci M, Ballotta A, Kunkl A, De Benedetti D, Kandil $H$, Conti $D$, et al. Influence of the timing of cardiac catheterization and the amount of contrast media on acute renal failure after cardiac surgery. Am J Cardiol. 2008;101:1112-8

https://doi.org/10.1016/j.amjcard.2007.12.011

44. Hennessy SA, La Par DJ, Stukenborg GJ, et al. Cardiac catheterization within 24 hours of valve surgery is significantly associated with acute renal failure. J Thorac Cardiovasc Surg. 2010;140:1011-7. https://doi.org/10.1016/j.jtcvs.2010.07.056

45. Murphy GS, Hessel EA 2nd, Groom RC. Optimal perfusion during cardiopulmonary bypass: an evidencebased approach. Anesth Analg. 2009;108:1394-417. https://doi.org/10.1213/ane.0b013e3181875e2e

46. Abramov D, Tamariz M, Serrick Cl, Sharp E, Noel D, Harwood S, et al. The influence of cardiopulmonary bypass flow characteristics on the clinical outcome of 1820 coronary bypass patients. Can J Cardiol 2003;19:237-43.

47. Rosner MH, Portilla D, Okusa MD. Cardiac surgery as a cause of acute kidney injury: pathogenesis and potential therapies. J Intensive Care Med. 2008;23:3-18. https://doi.org/10.1177/0885066607309998

48. Kanji HD, Schulze CJ. Difference between pre-operative and cardiopulmonary bypass mean arterial pressure is independently associated with early cardiac surgeryassociated acute kidney injury. J Cardiothorac Surg. 2010;5:71.

https://doi.org/10.1186/1749-8090-5-71

49. Boodhwani M, Rubens FD, Wozny D, Nathan HJ. Effects of mild hypothermia and rewarming on renal function after coronary artery bypass grafting. Ann Thorac Surg. 2009;87:489-95.

https://doi.org/10.1016/j.athoracsur.2008.10.078

50. Menasche P. The systemic factor: the comparative roles of cardiopulmonary bypass and off-pump surgery in the genesis of patient injury during and following cardiac surgery. Ann Thorac Surg 2001;72:2260-5; 5-6, 7-70.

https://doi.org/10.1016/S0003-4975(01)03286-6

51. Taylor KM. SIRS-the systemic inflammatory response syndrome after cardiac operations. Ann Thorac Surg. 1996;61:1607-8. https://doi.org/10.1016/0003-4975(96)00225-1

52. Birnie K, Verheyden V. Predictive models for kidney disease: improving global outcomes (KDIGO) defined acute kidney injury in UK cardiac surgery. Critical Care 2014;18:606.

https://doi.org/10.1186/s13054-014-0606-x

53. Perel A. latrogenic hemodilution: a possible cause for avoidable blood transfusions? Critical Care
2017;21(1):291.

https://doi.org/10.1186/s13054-017-1872-1

54. Karkouti K. Transfusion and risk of acute kidney injury in cardiac surgery. Br J Anaesth. 2012;109(1):29-38. https://doi.org/10.1093/bja/aes422

55. Koch CG, Li L, Sessler DI, Figueroa P, Hoeltge GA, Mihaljevic T, Blackstone EH. Duration of red-cell storage and complications after cardiac surgery. N Engl J Med. 2008;358:1229-39.

https://doi.org/10.1056/NEJMoa070403

56. Bove T, Calabro MG, Landoni G, Aletti G, Marino G, Crescenzi $G$, et al. The incidence and risk of acute renal failure after cardiac surgery. J Cardiothorac Vasc Anesth. 2004;18:442-5. https://doi.org/10.1053/j.jvca.2004.05.021

57. Haneya A, Diez C, Kolat P, Suesskind-Schwendi M, Ried M, Schmid C, Hirt SW. Re-exploration for bleeding or tamponade after cardiac surgery: impact of timing and indication on outcome. Thorac Cardiovasc Surg. 2015;63:51-7. https://doi.org/10.1055/s-0034-1390154

58. Kramer RS, Herron CR. Acute kidney injury subsequent to cardiac surgery. JECT 2015;47:16-28.

59. Grubb AO. Cystatin C-properties and use as diagnostic marker. Adv Clin Chem. 2000;35:63-99. https://doi.org/10.1016/S0065-2423(01)35015-1

60. Kaseda R, lino N. Megalin-mediated endocytosis of cystatin C in proximal tubule cells. Biochem Biophys Res Commun 2007;357:1130-4. https://doi.org/10.1016/j.bbrc.2007.04.072

61. Marx D. Metzger J. Proteomics and metabolomics for AKI diagnosis seminars in nephrology 2018;38(1):6387. https://doi.org/10.1016/j.semnephrol.2017.09.007

62. Fodor R, Grigorescu B. Plasma Neutrophil Gelatinase Associated Lipocalin (NGAL) - Early Biomarker for Acute Kidney Injury in Critically III Patients The Journal of Critical Care Medicine 2015;1(4):154-61. https://doi.org/10.1515/jccm-2015-0023

63. Haase M, Bellomo R. Accuracy of Neutrophil GelatinaseAssociated Lipocalin (NGAL) in Diagnosis and Prognosis in Acute Kidney Injury: A Systematic Review and Metaanalysis. American Journal of Kidney Diseases 2009;54(6):1012-24. https://doi.org/10.1053/j.ajkd.2009.07.020

64. Parikh CR, Thiessen-Philbrook H. Performance of kidney injury molecule-1 and liver fatty acid-binding protein and combined biomarkers of AKI after cardiac surgery. Clin J Am Soc Nephrol 2013; 8: 1079-88. https://doi.org/10.2215/CJN.10971012

65. Greenberg JH, Zappitelli recognition, and supportive measures. Nephron. 2018;140(2):105-10.

https://doi.org/10.1159/000490500 
66. Ünal EU, Özen A, Boysan E. Serum interleukin-18 as an early marker of acute kidney injury following open heart surgery. Türk Göğüs Kalp Damar 2014; 22(3): 483-8.

https://doi.org/10.5606/tgkdc.dergisi.2014.9610

67. Parikh CR, Jani A, Melnikov VY, Faubel S, Edelstein CL. Urinary interleukin-18 is a marker of human acute tubular necrosis. Am J Kidney Dis 2004; 43: 405-14. https://doi.org/10.1053/j.ajkd.2003.10.040

68. Lin CY, Chang CH, Fan PC, Tian YC, Chang MY, Jenq CC, et al. Serum interleukin-18 at commencement of renal replacement therapy predicts short-term prognosis in critically ill patients with acute kidney injury. PLoS One 2013;8:66028.

https://doi.org/10.1371/journal.pone.0066028

69. Blankenberg S, Luc G, Ducimetière P, Arveiler D,
Ferrières J, Amouyel P, et al. Interleukin-18 and the risk of coronary heart disease in European men: the Prospective Epidemiological Study of Myocardial Infarction (PRIME). Circulation 2003;108:2453-9. https://doi.org/10.1161/01.CIR.0000099509.76044.A2

70. Nadim MK, Forni LG, et al. Cardiac and vascular surgery-associated acute kidney injury: The 20th International Consensus Conference of the ADQI (Acute Disease Quality Initiative) Group. J Am Heart Assoc. 2018;7:e008834.

https://doi.org/10.1161/JAHA.118.008834

71. Bolliger D, Fassl J. Avoiding acute kidney injury after cardiac surgery: Simple and Easy? J Cardiothorac Vasc Anesth. 2018 Feb;32(1):223-4.

https://doi.org/10.1053/j.jvca.2017.09.045 